$\xi=-1$

\title{
The Street Vendors Perception to the Information of Public Access Disruption as the Effect of their Existence
}

\author{
Dorris Yadewani ${ }^{1 *}$, Syafrani $^{2}$ \\ ${ }^{1}$ AMIK Jayanusa Padang \\ ${ }^{2}$ Universitas Lancang Kuning Pekanbaru \\ *Corresponding author E-mail: dorris290@gmail.com
}

\begin{abstract}
Street vendors is a phenomenon in almost all regions in Indonesia, which is always a positive and negative impact on the region where the street vendor activity. The positive is the economy in a sustainable life in areas where street vendor activities, while the negative effects are disturbed some public access as a result of the existence of such street vendor, such as public roads are always jammed, the sidewalk is not functioning, trash increases or the environment increasingly neglected, area aesthetics will show discomfort. For the more crowded street vendor activities will have an impact upon the producer. However street vendor unaware that what was done to give effect to society because of disruption of public facilities. It is very necessary of information for the street vendor's understanding and perception to the impact caused by their presence in an area. The research was conducted by qualitative method with type research field investigations and descriptive analysis of the street vendor, managers, buyers and decision makers who do trading activities in S. Parman Street, UlakKarang Padang. Samples as research subjects were the street vendors as much as 5 people, managers, local government, the buyer and road users. The data used are primary data and secondary data. Data Collection Techniques conducted by observation, interview, and documentation while data analysis is conducted qualitatively by a descriptive approach. The findings and the results are show that the information obtained is correct in running its activities to seek fortune already utilizing public access such as sidewalk and road. Contributions to the street vendors are expected to have awareness in running its activities mainly on the utilization of public access and if you want to keep running its activities must be willing to abide by all the regulations set forth by the government, because it became a street vendor answers to some of the problems faced by street vendors as well as for the government attempted to manage and regulate the existence of street vendors to be in line with policies that have been set by the government for street vendors somehow able to overcome the problem of the existence of the public economy.
\end{abstract}

Keywords: Street vendors; public facilities; government policies.

\section{Introduction}

Street Vendors or street hawker, is one phenomenon that happen almost in every region in Indonesia, which always give positives and negatives impacts to the environment where they hold their activity. The positive impact is suistainable economic growth in their region, while the negative impact is the difficulty to access some of public facilities as the result of their activity, such problems with street and sidewalks, neatless of the their spots, over crowded, and low city aesthetic.

Nowadays in UlakKarang, mainly along the S Parman Padang Street, Street Vendors are growing fast and continously along with population growth. One of the indications of the Street Vendors growth is the increase of the traffic jam because Street Vendors use some parts of the road for their stands.

UlakKarang Region is one of the main roads in Padang City with dense population's activities start from housing, offices, education, and trading. Therefore, this region is a strategic place for Street Vendors to hold their bussiness. No wonder if lot of goods being sold there, start from foods and drinks, clothes, gasoline, children's toys, accessories etc. For Street Vendors, the more crowd the more they get their income. Beside that, the prices are cheaper than any other stores. It's a win situation too for buyer, because with the presence of Street Vendorsin the region, they are able to provide some ease in meeting the needs, Such as the prices are not too expensive, does not require extra time in finding the needs and does not require additional costs such as paying parking fees.

Based on interviews with some Street Vendors, in running their activities, Street Vendors often get related information about the use of public access, such as sidewalks and roads. As we know that sidewalks are public access that supposed to be used by pedestrians, but for the Street Vendors, the sidewalks are used to place their stuffs which make it difficult for pedestrians to access the sidelwalks. Likewise with the roads, the presence of Street Vendors in the roads often narrow the area of the road so often disrupt the riders and cause traffic jams, because they use some parts of the roads to place their merchandises.

The information gained from the public is about the negative side of the existence of Street Vendors in exploiting public access. Utilization of public access has to be done by Street Vendors because of several factors such as the lack of places provided by the government, unable to rent a place. However, the presence of Street Vendors gives a positive side to the community. The existence of Street Vendors are considered to help the community in meeting various needs at an affordable price. In this case the Street Vendors only need to be noticed and given decent facilities from the local government because their presence is not merely want to earn revenue but also the demands of the market that require 
Street Vendors, also the presence of Street Vendors are able to live the city, not quite and always dynamic.

From the above background, the writer is interested to examine the problem about "The Street Vendors Perception to The Information of Public Access Disruption as The Effect of Their Existence"The purpose of this study is to find out how the perception of the Street Vendors about information of the disruption of public access due to their existence in carrying out their daily activities.

\section{Literature Review}

\subsection{Perception}

Social perception is the perception of someone or others to understand people and others. In social perception there is something to be noticed, is the circumstances and feelings of other people today, in this place through non-list communication (eg : eye gaze, clothing, body language, etc.).oral and conditions more permanently that is behind everything that appears today(such as : intentions, traits, motivations) is thought to be the cause of the current conditions. It stems from the human tendency to always try to find out what is behind the symptoms that are caught with the senses. Thus, perception is a gift of meaning on the observation of an object. (Ninik Sriyanti, Istiqlaliyah Muflikhati, 2006)

According to Toha (2008: 143), "Perception is the cognitive process that everyone experiences in understanding every information about his environment through vision, sensing, appreciation, feeling and smell". Based on the definition it is understood that perception is the process of thinking that a person does understand any information that results from the catch of his senses, either through sight, hearing, feeling, appreciation, and smell (1).

Further, Social perception is a process that takes place on ourselves to know and evaluate others. Factors that affect perception: a. Internal factors, b. External Factors. Then the perception in society is divide into 2, namely : a. Public Perception of Physical Object, b. Public Perception of the Social Environment. (2)

In addition, perception is a psychological process that works in evaluating the environment it faces. According to (1) in man the process begins with the process of sensing, then the process of cognition that will ultimately be able to give meaning about the environment in the observed. In general, the perception to evaluate an environment encountered also involves other psychological components such as effective and psychomotor.(3)

From the above explanation can be drawn a conclusion that perception is an assessment done by other to physical objects or social environment in which the results of the assessment can be used to perform an evaluation.

Everyone has a tendency to see the same thing in different ways. The general characteristics of perception as follows :

a. Accepted stimulation must be in accordance with the morality of each senses, namely the basic sensory and each of the senses.

b. The world of perception has the dimension of space, we can declare top-down, broad-narrow and so on.

c. The objects or phenomena in the observation world have a structure integrated into the context.

d. Dimensions of perception have time dimensions such as slowly and so on.

e. The world of perception is a word of meaning, we tend to make observations or perceptions on the phenomena that have meaning for us that have to do(4).

\subsection{Public Access}

Every region always wants a public space that can be utilized by the entire community without any limit in carrying out various activities. Open space is an inter-building space covering all forms of landscape, hardscape (walkways and pedestrian paths), green spaces, canals, ponds, water towers, parks and urban break area
Open accommodates public activity and is space very closely related to environmental issues because of its function as natural environmental space of a city. In the context of improving the quality of public space, the most important thing in the design of open spaces is to support the occurrence of social interaction in it. This condition can be achieved with the arrangement of other physical elements of urban space, the building structure that defines the space well, placement support activities and accessibility that is open to the public (5).

In urban areas there are so-called public spaces. Public spaces in urban areas is a space that can be used by the public, can be park, garden, greenways, pedestrian, road, sidewalk, sports field, plaza, water level, rooftop, and all communal spaces outside the building(6).

Public spaces are a gathering place for city dwellers to engage in activities that can strengthen bonds as a community. Public spaces that include roads, parks, and other open spaces are potentially dynamic spaces to meet the needs of movement, communication and recreation for the citizens of their city. Because public space is usually open, accessible to anyone, in groups or individuals(7).

Meanwhile, based on Padang City Regulation Number 3 Year 2014 Section 13, about structuring and empowerment of Street Vendors, land public facility is land that is used for public facilities in accordance with the spatial plan area (8) . Carr(9) gave a number of theoretical notes on the function, type and variety of open public spaces. To elucidate its function, Carr underlines that public open space of status is a common property, therefore public open space serves to accommodate personal or group activities in the conduct of daily life as well as other special activities of a general nature. Public spaces can be regarded as nodes and communications, social binders to create interactions between groups of people(10)

Based on its function, public space can be classified in to : 1) public parks (city park, neighborhood park, mini garden); 2) field and plaza; 3) memorial park (memorial park); 4) a pedestrian walkways, pedestrian lanes in malls); 6) playing field. Each type of public open space function depends on the type(11).

\subsection{Street Vendors}

Currently the understanding of Street Vendors has evolved and seen from different points of view. The ILO provides a definition of the informal sector as a sector accessible to entrepreneurs of newcomers, using domestic economic resources, owned by families in small scale, using labor-intensive technology and technology tailored to the skills required, have not regulated by the government and engaged in competing markets (12).

Furthermore, Hutajulu (1985) provides restrictions on the informal sector, it is a field of economic activity which does not necessarily require formal education and high skills, and requires licenses and large capital to produce goods and services(13).

The street vendor is a person who relatively has little capital in the field of production and sales of goods (services) to supply the needs of a particular group within the community, the business is carried out in places deemed strategic in an informal environment. According to Portes and Walton (in Gilbert translated by Anshori 1996, p.100), In particular, the informal sector can be argued to subsidize the formal sector: its low-wage labour produces law-cast inputs for the formal sector and provides low-priced goods and services for formal sector workers(14).

The informal sector is also regarded as an economic system that has a role as a national economic safety valve has not been matched with protection by the government. Kinds of occupation which are included in the informal sector are, among others, Street Vendors, newspaper vendors, shoe polishers, booth keepers, beggars, prostitutes, and others. (Fatmawati, 2013)

While It is stated that "The informal sector in this case Street Vendors, is an unexpected sector, meanwhile in fact this sector is a sector which are arise from the growth of urban economy and urbanization products that occur in developing countries. The 
arrival of immigrants to a city which are largely unattended with sufficient skill and education, this appears an underclass society that is generally engaged in the informal section "(15).

According to the Regional Regulation No. 3 Year 2014 on the Arrangement and Empowerment of Street Vendors, the meaning of Street Vendors hereinafter referred as PKL is a business actor conducting trading business by using mobile or immovable business facilities, using city infrastructure, social facilities, public facilities, Land and buildings owned by the government and / or the private sector which are temporary and not settled (8).

Sociologically, PKL is a social entity in which there are groupings according to certain characteristics, such as: tribe, ethnic, language, custom, origin of area, kind of activity, and also religion (11). This entity has the same activity of trading in undue places in the urban planning for social and economic activity. Different goods and kinds of merchandise are usually related to differences in background and characteristic of Street Vendors(13).

Based on the definitions above, it can be concluded that Street Vendors (PKL) are traders who run their activities by utilizing public access to suffice the needs of life.

Actually, being a street vendor is not a goal in their life. But the limitations force them to be the Street Vendors. Where this Group generally has limitations to do business, among others: (1) lack of capital, (2) low level of education, and (3) Lack of access to government policies, information and economic and social facilities (15).

One characteristics of the informal sector is does not require a high level of education (Eka, 2009). The characteristics of Street Vendors are as follows: 1. Business activities are not well organized. 2. Not having a business license. 3. Irregular in business, whether viewed from the place of business and working hours. 4 . Clustered on the sidewalk or on the curbside of the protocol, in centers where are crowded. 5. Hawking his merchandise while shouting, sometimes running close to the consumer(16).

From various definitions above, it can be concluded that Street Vendors (PKL) are traders who run their activities by utilizing public access for the fulfillment of life needs

To become a street vendor is not really a goal in life, it's just the limitations make them become Street Vendors. (2) low level of education, and (3) lack of access to government policies, information and economic and social facilities(15).

One feature of the informal sector is that it does not require a high level of education (17).

As for the characteristics of street hawkers are as follows:

1. Business activities are not well organized

2. Do not have a business license

3. Not Regulated in the business, whether viewed from the place of business and working hours.

4. Clustered on the sidewalk or on the edge of the protocol street, in the center where crowds are crowded

5. hawking his merchandise while shouting, sometimes running toward the consumer(16).

With the many limitations that exist, forcing Street Vendors to continue to survive, such as the minimum of owned capital encourages Street Vendors to look for merchandise that can be resold, although little profit, open a small culinary business whose capital can be met from the existing savings and loans From family. While the type of business undertaken is still small and only able to survive so as not to require the skills and formal education in managing their business, then from the income side, the Street Vendors feel that the income can be to meet the daily needs, although small because income earned in everyday circumstances is considered sufficient for the necessities of life. This is in line with the results of research (1).

Then according to Agustinus (2001: 20), there are 3 factors that encourage Street Vendors, namely:1) Economic Aspect: empowerment of Street Vendors (micro business) needs to be conducted thoroughly, optimally and sustainably by fostering a conducive business climate, providing business opportunities, support, protection and the widest possible business development. 2) Social aspects: In relation to the strategy of handling PKL, the social aspect includes: reinforcement. 3) Environmental aspect : The location of street vendors, in general is not separated from the problem of cleanliness and beauty of environmental, where this aspect can have a selling point ( Image of the location) (1).

In line with the results of research Anton Sudjarwo on Public Policy in The Implementation of Pattern Structuring PKL In Malang City state that in addition to the high rate of population growth of existence of street vendors are also caused by several driving factors, among others : 1) Low level of education., based on the existing data, most of the education level of people in Indonesia is still very low compared to other developing countries. This condition is certainly encouraging people to try to survive without a more educative effort. But they are looking for an easier way, one of them being a sword of five. 2) Economic factors and capital, as we know before that the capital owned by street not have much capital. 3) Jib background factors, in general people who work as street vendors are those who have previous jobs, but because the works is uncertain, then they generally take the road by becoming street vendors for their work to be uncertain. 4) Environmental influence factor, generally a street vendor resides (residence) at a location that becomes the center of the street vendors.(Sudjarwo, 2012)

Furthermore, the factors that influence someone in determining the kinds of their occupation include: education, age, literacy and numeracy, training and work experience (18) Meanwhile, research report of Joni Joko Sarjono, Agus Sikwn, Donatianus BSEP (2014) on Government's Role in Empowerment of Street Vendors in district of East Pontianak stated that the factor causing a seller to be a street vendor (PKL) is influenced by internal factor (Intern factor) Such as family economic conditions and jobs (11). Furthermore, through the business of selling in Street Vendors the owners earn income by independent effort to continue their life as a family. They racked their brains to start a business in a rally and independently(19).

\section{Methodology/Materials}

The research was conducted by qualitative method with field investigation and descriptive analysis.

\subsection{Research Sites}

This research was conduct in Padang City, that is S. Parman Street, Ulak Karang by reason of the growth of Street Vendors by utilizing public access in this location quite rapidly.

\subsection{Research Subject}

The subjects in this study are Street Vendors, managers, buyers and policy makers who conduct trading activities on $\mathrm{S}$. Parman Street, Ulak Karang, Padang. Sample as the subject of research is 5 Street Vendors, 2 managers, 2 local governments, 2 buyers and 2 road users.

\subsection{Type and Data Source}

The data are using the first and second data.

1. Primary data is data collected from respondents that are useful to answer the existing problems, primary data obtained directly from the field with structured interview techniques to obtain the desired information. Primary data contains the identity of respondents, jobs, income and others.

2. Secondary Data is data obtained or collected from some important information, related agencies such as Padang City Market Office, literature study, and the literature relating to this research either directly or indirectly. 


\subsection{Data Collection Techniques}

1. Observation is observation is to conduct direct observation in field related to all kinds related to things to be studied, among others, is the condition of research location, condition of existing facilities and pre-existing facilities, Street Vendors of S.Parman Street, Padang.

2. Interviews are activities carried out in the form of direct communication with buyers face to face about matters relating to research.

3. Documentation is done by taking pictures related to the activities at the location of Street Vendors.

4. Data analysis done in a way qualitative with descriptive approach with the intention of organizing and sorting research data into patterns, categories, and units of data description so it can be know from the research with the problems that have been set.

\section{Results and Findings}

\subsection{Characteristic of Informant}

\subsubsection{Education Level}

To see the characteristic of Street Vendors on S. Parman Street, Padang, from the last educational level of informants, can be seen in table below :

Table 1: Distribution by Level of Education

\begin{tabular}{|c|c|c|c|}
\hline \multirow{2}{*}{ Num. } & \multirow{2}{*}{ Level of Education } & \multicolumn{2}{|c|}{ Frequency } \\
\hline & & People & Percentage $(\%)$ \\
\hline 1 & Elementary School & 1 & $20 \%$ \\
\hline 2 & Junior High School & - & - \\
\hline 3 & Senior High School & 2 & $40 \%$ \\
\hline 4 & Bachelor Degree & 1 & $20 \%$ \\
\hline 5 & Others & 1 & $20 \%$ \\
\hline \multicolumn{2}{|r|}{ Total } & 5 & 100,0 \\
\hline
\end{tabular}

Source: Results of Field Research 2016

From five informant data taken, $20 \%$ of elementary education level, $40 \%$ high school education level, $20 \%$ education leve Bachelor Degree and $20 \%$ other education level. Low pedagogical education is the one of main reasons for pursuing a job. The result of this research is in line with research report of Widjajanti about Characteristic of Small Street Trader's Activity in City Room (Case Study: Tembalang Education Area, Semarang City) That is Most of last education Street Vendors in Tembalang is Junior High School and Senior High School. At this level of education, Street Vendors have limited abilities and skills, making it difficult to enter into the formal sector. Difficult to get a job, giving chances to Street Vendors to work according to ability. (1)

\subsubsection{Based on Capital Initial}

Initial capital of Street Vendors in carrying out their daily activities can be seen in the table below :

Table 2: Distribution Table Based on Initial Capital.

\begin{tabular}{|c|c|c|c|}
\hline \multirow{4}{*}{ Tum. } & \multirow{2}{*}{ Capital Initial } & \multicolumn{2}{|c|}{ Frequency } \\
\cline { 3 - 4 } & & People & Percentage \\
\hline 1 & $<100.000$ & 3 & $60 \%$ \\
\hline 2 & $100.000-500.000$ & 1 & $20 \%$ \\
\hline 3 & $>500.000$ & 1 & $20 \%$ \\
\hline \multicolumn{2}{|c}{} \\
\hline
\end{tabular}

Source : Results of Field Research 2016

From 5 informant data taken, $60 \%$ initial capital of Street Vendors in running its activity is $<$ Rp. $100.000,20 \%$ initial capital of Street Vendors in carrying out its activities are in the range of $\mathrm{Rp}$. 100,000 - Rp. 500,000 and $20 \%$ of initial capital Street Vendors is above Rp.500.000. This shows that with low capital trigger busi- ness actors to more easily enter the business so that predicted this location will be met by Street Vendors in the future.

The results of this study in line with research reports conducted by (20) on Public Policy in the Implementation of Pattern of Street Vendors in Malang City stated that the capital owned by Street Vendors is relatively small, this is what drives someone to Street Vendors, because they do not have Lots of capital (2)

\subsubsection{Distribution of Street Vendors Based on the Loca- tion}

Street Vendors in the area of S. Parman Street, Padang, tends to occupy available public spaces such as sidewalks and road bodies.

Table 3: Based on Street Vendors Location

\begin{tabular}{|c|c|c|c|}
\hline \multirow{2}{*}{ Num. } & \multirow{2}{*}{$\begin{array}{c}\text { Location of Street Ven- } \\
\text { dors }\end{array}$} & \multicolumn{2}{|c|}{ Frequency } \\
\hline & & People & Percentage (\%) \\
\hline 1 & Sidewalk & 3 & $60 \%$ \\
\hline 2 & Roadside & 2 & $40 \%$ \\
\hline & Total & 5 & 100,0 \\
\hline
\end{tabular}

Source : Results of Field Research 2016

In this case $60 \%$ of Street Vendors declare to use sidewalks as a place to sell and $40 \%$ of Street Vendors declare using the street body to sell. Overall, the Street Vendors in carrying out their activities are using roads and sidewalks because the Street Vendors do not have the cost to pay the rent to the city government.

The results of this study are in line with research conducted by EkoHandoyo on the Meaning of Public Spaces for Street Vendors: The Study of Resistance to Eviction(6). In the study said that public spaces or locations to sell Street Vendors is a strategic place that must be maintained from the intervention of others. This is because (1) the Street Vendors do not have a permanent place to run the business, (2) the choice at the roadside location, because it gives the buyer and the service user the interest to come. (3) Similar results are also shown by (21) on the Perception of Street Traffickers Against Order Conducted By Pekanbaru City Government, Case Study At HR. Soebrantas Street, Tampan Districts) concluded that the factors that cause Street Vendors to sell on HR. Soebrantas Roadside. HR. Soebrantas Street is due to low economic conditions, no need to pay any fees, and strategic location. (4)

Study of Characteristic of Use of Street Vendors Room (PKL) in Ex-Market Area Lawalata, Case Study Taman SurapatiKendari City that the existence of Street Vendors in the Ex-Market Lawata's Area or precisely on Suropati Park is needed by the general public of various groups, both level of education, income and work. Street Vendors can provide comfort not only cheap and quality but also can be achieved with a very high level of accessibility without leaving the vehicle. (5)

The results of this study In line with the results of research (14), Street Vendors are not solely burden or disruption to the beauty and order of the city. The Street Vendors also have the right to live and earn a decent income, but these reasons should not be used by Street Vendors to try without obeying the rules because not all locations can be used as a place of business. The Street Vendors are also an asset and an economic potential if it can be properly managed. Problems that arise in relation to the Street Vendors are caused by the lack of space to accommodate the activities of Street Vendors in urban areas. (6)

So, from some of the research supports that strategic location is one of the trigger factor of Street Vendors in carrying out its daily activities to seek fortune.

\subsubsection{Distribution of Street Vendors by Type of Goods}

Table 4: Based on Goods Characteristics

\begin{tabular}{|c|c|c|c|}
\hline \multirow{2}{*}{ Num } & \multirow{2}{*}{ Goods Characteristics } & Frequency \\
\cline { 3 - 4 } & & People & Percentage \\
\hline 1 & Services & 3 & $60 \%$ \\
\hline
\end{tabular}




\begin{tabular}{|l|l|l|l|}
\hline 2 & Foods and Drinks & 1 & $20 \%$ \\
\hline 3 & Clothes and Bags & 1 & $20 \%$ \\
\hline \multicolumn{2}{|c|}{ Total } & 5 & 100,0 \\
\hline
\end{tabular}

Source : Results of Field Research 2016

From 5 data of informants taken, $60 \%$ Street Vendors stated that merchandise included service category, 20\% Street Vendors stated that merchandise included category of food and beverage type and $20 \%$ stated that merchandise belongs to other type that is clothes and bags. For model choice and other types of bags and clothing are also more options including prices can also be cheaper in comparison to existing in the market or in official place. Lots of business variations show the creativity of business actors to reduce their level of competition.

In line with Besse Asniwaty's research report, Characteristics of Street Vendors on the Mahakam River coast is generally women with very productive age level but not supported by adequate education level. Their low level of education leads to a level of ability to understand a very low code or policy, the most important thing for them is how to survive and support the family, the pressure on that need makes them more creative to create jobs for themselves and their families(22).

\subsubsection{Based on Monthly Income}

Income is one factor for informants that Street Vendors to survive. More can be seen in table below :

Table 5: Based on Monthly Income

\begin{tabular}{|c|c|c|c|}
\hline \multirow{2}{*}{ Num } & \multirow{2}{*}{ Level of Income } & \multicolumn{2}{|c|}{ Frequency } \\
\cline { 3 - 4 } & & People & Percentage \\
\hline 1 & $<100.000$ & 1 & $20 \%$ \\
\hline 2 & $100.000-500.000$ & 2 & $40 \%$ \\
\hline 3 & $>500.000$ & 2 & $40 \%$ \\
\hline \multicolumn{2}{|c|}{ Total } & 5 & 100,0 \\
\hline
\end{tabular}

Source : Results of Field Research 2016

From 5 informant data taken, 20\% Street Vendors stated that monthly income under Rp.100.000, 40\% Street Vendors stated that monthly income is in the position of Rp.100.000- Rp.500.000 and $40 \%$ Street Vendors again stated that monthly income is above Rp.500.000.

It can be concluded that the income of this Street Vendors is uncertain So it can be concluded that the job of becoming a street vendor is one way done in order to fulfill the necessities of life. This is in line with the results of research (1). This is in line with research report (1) on the Public Perception of Street Vendors in Banda Aceh City that is with the many limitations that exist to force the Street Vendors to continue to survive, such as the lack of capital owned push the Street Vendors to find goods Merchandise that can be resold even if the profit is small, open small culinary business whose capital can be fulfilled from the existing savings and loans from the family. While the type of business is still small and only able to survive so as not to require the skills and formal education in managing their business, then in terms of income, the Street Vendors feel that the income earned can be to meet the daily needs, although small but because of income Which is obtained daily in nature is considered sufficient for the fulfillment of life needs. (7)

\subsubsection{Based on Job Analysis}

\begin{tabular}{|c|c|c|c|}
\hline \multirow{2}{*}{ Num } & \multirow{2}{*}{ Job Analysis } & \multicolumn{2}{|c|}{ Frequency } \\
\cline { 3 - 4 } & & People & Percentage \\
\hline 1 & Main & 3 & $60 \%$ \\
\hline 2 & Side & 2 & $40 \%$ \\
\hline \multicolumn{2}{|c|}{ Total } & 5 & 100,0 \\
\hline
\end{tabular}

Source : Results of Field Research 2016

Of the 5 informant data taken, $60 \%$ stated that the work to be Street Vendors is the main job and $40 \%$ stated that the job et vendor is a side job. This shows that being a street vendor is a major profession
Furthermore according to Augustine (2001: 20), there are 3 factors that encourage Street Vendors are :

1. Economic Aspect : The empowerment of Street Vendors (micro business) needs to be conducted thoroughly, optimally and continuously by fostering conducive business climate, giving business opportunity, support, protection and business development as wide as possible.

2. Social Aspect: Related to the strategy of handling Street Vendors, social aspect concerned Among others include: institutional strengthening, quality of human resources (education and skill level), population movement, and crime.

3. Environmental Aspects: The location of Street Vendors in general cannot be separated from the problem of cleanliness and beauty of the environment, where this aspect can have a sale value (image of the location).

Caused by several other driving factors. Several other promoting factors choose to become Street Vendors:

1. Low level of education. Based on existing data, most of the education level of society in Indonesia is still very low compared to other developing countries. This condition is certainly encouraging people to try to survive without a more educative effort. But they are looking for an easier way, one of which is by becoming a street merchant.2. Economic and Capital Factor. As we know before that the capital owned by Street Vendors is very small, this is what drives someone to Street Vendors, because they do not have much capital.3. The Background Factor of job. In general, people who work as Street Vendors are those who have previous jobs, but because the work is uncertain, then they generally take the road by becoming Street Vendors for their work to be not fixed.4. Environmental impact Factor. Generally a street vendor resides (residence) at a location to be center of Street Vendors (2)

\subsection{Perception of Street Vendors against information on the Decline of Public Access as a result of the Existence of Street Vendors.}

Perceptions of Street Vendors on information disruption of public access as a result of their presence on S.Parman Street, Padang, explained by 5 informants below :

1. "It's a common thing to hear, that our presence on the sidewalk is sanggar interfere with pedestrians. But want how else, rent a place it costs rent, while klo here do not need to pay rent even though also often cats - kloklo there officers who raid.

2. "I am very aware that selling using the road is very dangerous for my own safety or others, such as motorists. But this area is a strategic area that is accessed by many people

3. "This area is quite strategic, there are many buyers and there is no cost to pay the rent even if there is only for the electricity money that the payment is not too burdensome us. If in the market, must pay the rental fee with the amount and timeframe that has been determined.

4. $\quad$ "I held merchandise using the road body in order for my merchandise to be seen by every prospective buyer who pass this way even if at the time the prospective buyer passes this road does not intend to buy. If you have to sell in a place that has been determined, many administrative requirements that must be completed and I do not want complicated ".

"Although it is considered to often interfere with the smoothness of traffic and the cause of congestion I will continue to sell by utilizing this facility, because this is the only way I survive in an effort to meet the needs of everyday life.

"It's hard to find a place to sell without any rental fees, even if there are many procedures. Meanwhile, if on this sidewalk, just stay alone. If anyone asks us to pay or evict us, we just move to find a new place. 


\subsection{Key Informant's Perception on the Behavior of Street Vendors on S. Parman Street, Padang}

1. Key Informant (Buyer)

Buyer 1 :

"The presence of a pkl especially who sells food in this area that uses the sidewalk facilities, very helpful for me, in addition to many options, at the time of interaction did not have to get off the vehicle, no need to find parking locations"

Buyer 2:

"Many find ease in the fulfillment of daily needs, especially I do not have a lot of time to find my needs. In addition to many options, not complicated and does not require additional fees for parking fees.

In line with the results of research conducted by Ismanidar et al (1) Public Perception Against Trawler Traders in the City of Banda Aceh on Public perceptions of Street Vendors are divided into two types, namely positive perceptions and negative perceptions Positive perception among the people feel the benefits of Street Vendors and they often claim to transact in Street Vendors because the price of goods sold cheaper with the same quality as products sold on supermarket and shops. While the negative perception of street hawkers according to the public is its existence can disturb the order and cleanliness of the city because of the condition of Street Vendors who chaotic and not neatly arranged, they also often throw garbage carelessly. Another negative impact of Street Vendors that can disrupt the smooth flow of traffic and cause congestion on the streets of Banda Aceh because the location where they trade on average do not have a parking lot so that buyers who want to transact in Street Vendors often park their vehicles on the road.

In line with the results of research conducted by Shirdata abou Phenomenon of Street Vendors in the Viewpoint of Philosophy of Law and Consumer Protection Study which states that from the perspective of the end consumer, Street Vendors are something that is really needed. They prove to still exist because what they sell is something that suits the needs of local consumers. For example, even in a mall or shopping center there is a food court that sells all kinds of dishes, in fact there is still a group of people who work in that environment that is not including this food court consumer group. Drivers who are taking their employers shopping or some of the mall employees who want to save money, will tend to choose Street Vendors near the location. In line with research conducted by Sutarjo 2016 on Street Vendors Externalities states for some people, shopping or strolling on Street Vendors selling merchandise is considered a recreation.

2. Pedestrian

\section{Pedestrian 1:}

"Disturbing traffic flows and causing congestion, especially at 16:00 to 18:00 because it is a time of heavy traffic (school and office activity time ends)

Pedestrian 2:

"Helping if there is a need that must be fulfilled in a short time, because there are already pkl punched the roadside. So it makes it easy for me to interact directly with pkl without having to get off the vehicle.

In line with research conducted by (23) on Street Vendors Externalities, It is suggested that the existence of Street Vendors cause traffic disturbance because it is on the roadside or sidewalk causing congestion and dirt. The presence of Street Vendors also causes rubbish to scatter and cause buyers to park their motor vehicles out of place.

3. Policy Stakeholders

\section{Policy Stakeholders 1:}

"I only run the duty as the implementation of public order and peace of the community and provide protection to the community. Especially the unrest caused by the presence of Street Vendors who use public access in carrying out their daily activities, some- times the Street Vendors are also often stubborn and some are aware That the activities that are done is wrong but want moreover when we do not do the curbing again they resume their daily activities. Besides, in order to carry out the curbing, we also bring a letter of work to control.

\section{Policy Stake Holders 2:}

Market Service "The Street Vendors in this area especially along S.Parman Street, still we do not manage well and will be done if the public access when the user is feeling disturbed. In order to curb our officers always give advice and socialization to the Street Vendors about the utilization of public access in performing daily activities is not justified. If the Street Vendors insist or stubbornly then the officers will crack down on the Street Vendors

"In line with the results of research conducted on the Performance of Police Unit of Civil Service In Policy of Guidance and Control of Street Vendors in the Pancasila District of Karanganyaryang Regency stated that Basically, the implementation of policy made by Satpol PP in policy Guidance and discipline of Street Vendors in Pancasila Park, Karanganyar Regency is a way to overcome the problems caused by Street Vendors in Karanganyar Regency

4. Manager

\section{Manager 1:}

The presence of Street Vendors is an additional source of income, because this Street Vendors are illegal then we also give permission for the Street Vendors to take advantage of existing facilities along the area of S.Parman Street on condition that they have to pay security money of Rp.2000 per Street Trader. With note we do not guarantee if there is eviction or policing by civil service police

\section{Manager 2:}

Causing problems between Street Vendors if an increase in the number of Street Vendors with the same product, although at the beginning we have provided information that the deposit given is only limited to the provision of trade locations along the S. Parman Street, Padang. But the average presence of Street Vendors is one of our livelihoods.

\section{Conclusion and Suggestion}

\subsection{Conclusion}

Based on the results of research and discussion in research on the Perception of Street Vendors on Utilization of Public Access to the Presence of Street Vendors on S.Parman Street Padang can be concluded:

The presence of Street Vendors in running their activities to seek fortune can not be separated from the utilization of public access that is considered strategic and able to revive the economy in a sustainable manner.

Activities undertaken by Street Vendors along S Parman street has not received special

\subsection{Suggestion}

It is expected to have awareness in carrying out its activities, especially on the utilization of public access and if you want to keep running its activities must be obedient to all regulations that have been settled by the government because becoming Street Vendors is the answer of some problems faced by the Street Vendors For the government

Trying to manage and manage the existence of Street Vendors to be in line with the policy set by the government because after all the existence of Street Vendors are able to overcome the problems of the community economy. 


\section{References}

[1] Ismanidar ASU. Persepsi Masyarakat Terhadap Pedagang Kaki Lima Di Kota Banda Aceh. Ilmiah Mahasiswa Pendidikan Kewarganegaraan. 2016;1:147-57.

[2] Andriani F. Persepsi Pedagang Kaki Lima Terhadap Penertiban Yang Dilakukan Oleh Pemerintah Kota Pekanbaru, Studi Kasus Di Jl. HR. Soebrantas Kecamatan Tampan). JOM FISIP. 2016;3:1-15.

[3] Hartina Alwi MA. Persepsi Pengunjung Terhadap Ketersediaan Sarana Penunjang Ruang Publik Kota Mara, Bau Bau, sulawesi Tenggara. Wilayah dan Kota Maritim. 2013;1(1):1-8.

[4] Ruth Casarena Saragih R. Analisa Pendapatan dan Persepsi Petan Keramba Terhadap Keberadaan PT. Aquafarm Nusantara ( Studi Kasus : Petani Keramba Dikecamatan Girsang Sipangabolon Kabupaten Simalungun. Ekonomi Dan Keuangan. 2013;1(39-50).

[5] Sunaryo RG. Perubahan Setting Ruang dan Pola Aktivitas Publik di Ruang Terbuka Kampus UGM. Seminar Nasional Riset Arsitektur dan Perancanagn (SERAP)I. 2017:175-82.

[6] Handoyo E. Makna Ruang Publik Bagi Pedagang Kaki Lima : Studi tentang Resistensi terhadap Penggusuran. Prosiding Seminar Nasional Multi Disiplin Ilmu \& Call For Papers UNISBAK (SENDI_UI). 2105(1):978-9.

[7] Sumarwanto. Pengaruh Pedagang Kaki Lima Terhadap Keserasian Dan Ruang Publik Kota Di Semarang. UNTAG. 2012;1:84-92.

[8] Meng J. Unpacking the relationship between organizational culture and excellent leadership in public relations: An empirical investigation. Journal of Communication Management. 2014;18(4):363-85.

[9] Carr S. Public space: Cambridge University Press; 1992.

[10]Uzhma ASPP. Pemanfaatan Ruang Terbuka Publik Oleh Pedagang Kaki Lima Di Kawasan Alun KApuas, Kota Pontianak. Agora $0205 ; 15$.

[11] Sarjono JJ, Sikwan A. Peranan Pemerintah Dalam Pemberdayaan Pedagang Kaki Lima Di Kecamatan Pontianak Timur. Tesis PMISUNTAN-PPS. 2015:1-14.

[12] Sigit Wibawanto HP. Pengaruh Akses Permodalan, Pengelolaan Bisnis Terhadap Pemberdayaan Usaha Pedagan Kaki Lima Dengan Peran Pemerintah Daerah Sebagai Variabel Intervening ( KAsus PKL DI Kabupaten Kebumen). Fokus Bisnis. 2008;7(02).

[13]Ibnu Sulthan Suneth HI. Implementasi Kebijakan Publik Tentang Penataan dan Pemberdayaan PKL ( Studi di Kec Sidoarjo, Kab Sidoarjo). JKMP. 2014;2:93-102.

[14] Irianto AM. Strategi Adaptasi PKL Kota Semarang : Kajian Tentang Tindakan Sosial. Kommunitas. 2014;6(1):70-90.

[15] Utami T. Pemberdayaan Komunitas Sektor Informal Pedagang Kak Lima (PKL), Suatu Alternatif Penanggulangan Kemiskinan Sosiologi. 2009:114-23.

[16] Palijama F. Penataan Pedagang Kaki Lima Pasar Mardika ( Kajian Kebijakan Penataan Pemerintah Kota Ambon ). Populis. 2013;7:3143.

[17]Dewi PM. Partisipasi Tenaga Kerja Perempuan dalam Meningkatkan Pendapatan Keluarga. JEKT. 2012;2:119-24.

[18] Khaafidh M, Poerwono D. Faktor - faktor Yang Mempengaruhi Keputusan Tenaga Kerja Untuk Bekerja Di Kegiatan Pertanian ( Studi Kasus : Kabupaten Rembang ). Diponegoro Journal Of Economics. 2013;2:1-13.

[19] Kurniawati J. Analisis Kebijakan Strategi Pemberdayaan Pedagang Kaki Lima ( PKL ) Oleh Pemerintah Kota Surakarta. Kearifan Lokal Nilai Adiluhung Batik Indonesia Untuk Daya Saing Internasional. (10):978-9

[20] Sudjarwo A. Kebijakan Publik Dalam Pelaksanaan Penataan Pola Pedagang Kaki Lima Di Kota Malang. Reformasi. 2012;2:2-6.

[21] Andriani F, Yusuf Y. PERSEPSI PEDAGANG KAKI LIMA TERHADAP PENERTIBAN YANG DILAKUKAN OLEH PEMERINTAH KOTA PEKANBARU (Studi Di Jalan HR. Soebrantas Kecamatan Tampan). Jurnal Online Mahasiswa (JOM) Bidang Ilmu Sosial dan Ilmu Politik. 2016;3(2):1-15.

[22] Asniwaty B. Karakteristik Pedagang kaki Lima Di Pesisir Sungai Mahakam Samarinda. Eksis. 2010;6(2):1440-4.

[23] Sutarjo. Externalities, Street Vendors. 2016. 